\title{
Истощение накачки и чистка пучка при ВКР-генерации в многомодовом градиентном световоде
}

\author{
$\underline{\text { А.Г. Кузнецов }}^{1, *}$, С.И. Каблуков ${ }^{1}$, Е.В. Подивилов ${ }^{1,2}$, С.А. Бабин ${ }^{1,2}$ \\ ${ }^{1}$ Институт автоматики и электрометрии СО РАН, Новосибирск, Россия \\ ${ }^{2}$ Новосибирский государственньй университет, Новосибирск, Россия \\ *E-mail: leks.kuznecov@gmail.com
}

DOI: $10.31868 /$ RFL2020.109

В последнее время рамановские лазеры на основе градиентных световодов (GIF) привлекают большое внимание из-за возможности эффективного рамановского преобразования сильно-многомодового (М2 = 20-30) излучения мощных лазерных диодов (ЛД) в стоксов пучок хорошего качества (M2 =2-3) в полностью волоконной схеме с резонатором на основе волоконных брэгговских решеток (ВБР) и с заведением накачки с помощью волоконных объединителей [1].

Используя коммерчески доступные GIF и ЛД 9хx-нм, такие лазеры могут генерировать излучение с хорошим качеством пучка на длине волны $<1$ мкм, где генерация одномодовых $\mathrm{Yb}$ волоконных лазеров практически невозможна. Объединение излучения нескольких (до 3) высокомощных ЛД в GIF с сердцевиной 100 мкм посредством многомодового 100 мкм волоконного объединителя накачки позволяет в данной схеме увеличить суммарную мощность накачки до 200 Вт и генерировать стоксовое излучение с выходной мощностью 50-60 Вт на длинах волн 954 [1] и 976 [2] нм с использованием ЛД 915 и 940 нм, соответственно. При этом оптимизация поперечного профиля ВБР, записанной фемтосекундными импульсами в области сердцевины GIF позволяет улучшить качество пучка до М2 2 без потери эффективности преобразования [2]. Хотя эффект чистки комбинационного рассеяния в волокнах с градиентным показателем преломления хорошо известен, его объяснение - качественное [4]. Оно основано на сложном анализе интегралов перекрытия между различными поперечными модами пучков накачки и стоксовой волны, показывающее более высокий коэффициент усиления слабого сигнала (т.е. около порога ВКР лазера) для стоксовых мод низкого порядка при случайной накачке GIF.

В данной работе представлены экспериментальные измерения профилей пучка накачки как вблизи рамановского порога, так и значительно выше порога (когда истощение накачки становится значительным) в 100 мкм GIF лазере с ЛДнакачкой, а также соответствующие профили стоксова пучка, генерируемые на длине волны 976 нм. Построена аналитическая модель для анализа ВКР усиления и профилей пучка. Обсуждается роль различных линейных и нелинейных эффектов в формировании выходного пучка.

Работа выполнена при частичной поддержке гранта РФФИ (19-52-53021).

\section{Литература}

[1] S.A. Babin, E.A. Zlobina, et al, J. Sel. Top. Quantum Electron. 24, 1400310 (2018).

[2] A.G. Kuznetsov, S.I. Kablukov, et al, Laser Phys. Lett. 16 (10), 105102 (2019). 